\title{
THE NEW PERSPECTIVE(S) ON PAUL AND ITS IMPLICATION FOR ETHICS AND MISSION
}

\author{
Jacobus Kok \\ University of Pretoria
}

\section{ABSTRACT}

In this article the New Perspectives ${ }^{1}$ on Paul and its implication for Pauline ethics will be discussed as well as the relationship it has to the understanding of the missionary dynamics in Paul. The article begins with the history of the development of the New Perspectives on Paul and continues by exploring James Dunn's contribution to the understanding of the controversy in the Letter to the Galatians regarding works

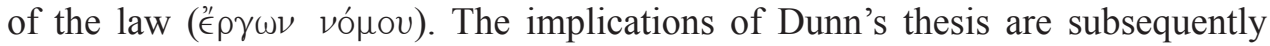
accounted for and brought in relation with mission and ethics in the early church. Thereafter, the contribution of N. T. Wright is discussed with special reference to his understanding of the righteousness of God and the righteousness of those who come to faith in Christ.

\section{Introduction}

In his book "Reinventing Paul", Gagner (2000) investigates Paul and his relationship to Judaism against the background of the New Perspectives on Paul. Gagner rightly refers to the fact that after the devastation of World War II, there has been a growing outreach to Judaism by Christian leaders and scholarship. ${ }^{2}$ This was unfortunately not the case in the past, and especially during the all important Aufklärung. The predominant view of Judaism as constructed by the (Reformed) Western church was one of extreme legalism. Leading exponents of this view were F. Weber, E. Schürer, W. Bousset and P. Billerbeck. In Weber's influential book System der altsynagogalen palästinischen Theologie, he developed the thesis that the Jewish religion of Paul's day was nothing less than a legalistic religion in which the people of God earned their righteousness by means of good works (works-righteousness). Weber influenced other scholars like W. Bousset who again influenced the German scholar R. Bultmann who uncritically took over the point of view of Weber. Consequently, the view that Judaism was a legalistic works- 
righteousness religious system, antithetical to Christianity and its faith-righteousness was therefore uncritically excepted. In most commentaries and theologies of the time, this view was the predominant one.

Against the background of the predominant legalistic view of Judaism, underlying discourses started to develop. A decade before the outbreak of World War II (1927-1930), G. F. Moore (see Dunn 2008:5-6 n. 20) published his Judaism in the first centuries of the Christian era: The age of the Tannaim in which he painted a new picture of Judaism that was less legalistic. Others, like the Jewish theologian C. G. Montefiore (1915) also criticised the misrepresented view of Weber and appealed in favour of the diversity of literature within rabbinic literature itself. According to Montefiore, Judaism viewed the law as a gift from God and in no way interpreted it in a legalistic works-righteousness way.

Unfortunately, the work of Moore and Montefiore was not taken seriously by New Testament scholarship. The predominant view of Judaism as a cold legalistic meritearning religious system prevailed. This view not only predominated within New Testament scholarship, but also fueled someone like Hitler and his anti-semitic program which culminated in one of the world's most devastating events.

Moore and Montefiore were not the only ones who proposed an alternative view on Judaism. As early as 1963, the Lutheran Bishop K. Stendahl (1963:199-215) published his "Paul and the introspective conscience of the West". According to Stendahl, Paul remained a Jew until the end of his life and did not view himself as a Christian, that is, part of some religion other than Judaism. The implication is that Paul's conversion must be understood not as a conversion from Judaism but a conversion within Judaism. Consequently, Paul saw his own calling as a calling by God to be an apostle, sent by God to the Gentiles, within the (original) covenant plan of God. Thus Luther's interpretation of Paul, as being converted from Judaism into a new religion presents a misunderstanding of Paul. According to Stendahl (1963:199-215), Paul was closer to Judaism than has previously been recognised. Stendahl's perspective differs fundamentally from scholars like Weber $(1880)^{3}$ who maintained the view that Judaism was essentially a religion of legalism.

More than a decade after Stendahl's work, Sanders (1977) published his seminal work, Paul and Palestinian Judaism. Aware of the fact that the previous work done by scholars like Moore had little impact on the academic community, Sanders was determined that his own polemical protest would be unmistakable (Dunn 2008:6 n. 20). Sanders conducted a thorough study of Jewish literature (see 1 QS 11.11-15; Psm 103:10; Dan 9:16-18, etc) and came to the convincing finding that the traditional understanding of Judaism as a religion that attempted to earn their right standing before God, was a misrepresentation of Judaism altogether. He argued that Judaism was not obsessed with works-righteousness and the effort of man to win the favour of God to earn righteousness. Judaism's theology of salvation recognises first of all the initiative of a loving God who made a covenant with his people. Members of the covenant were 
already accepted by God and therefore they did not need to do good works to earn that favour. Obedience to the law was seen as the way in which the covenant members stayed within the covenant and maintained their membership. The works of the law are thus not to be seen as a means to get into the covenant but a means to stay in the covenant Sanders (1977:420, 543; cf. also 75, 236, 420, 544). To explain the latter, Sanders used the term "covenantal nomism" (Bundesnomismus) which represented the inter-relationship between divine initiative (covenant) and the response of those who are within that relationship (nomism) (Dunn 2008:6-7). Consequently, Sanders argued that the traditional Lutheran understanding of Paul and his view of Judaism were nothing less than erroneous. He illustrated that scholars like Billerbeck employed only certain elements of Judaism in their thesis to illustrate the legalism of Judaism, but conveniently did not consider the evidence that pointed in the opposite direction. Towards the end of his book, Sanders discusses the implication of his new understanding of Second Temple Judaism and its implication for the understanding of Paul. ${ }^{4}$ Sanders furthermore objected to the caricature of Judaism that was constructed by Christian scholarship, something that has been picked up by many, like J. Parkes (1936:120), who Sanders (1977:6) quotes as saying that: “...if Paul was really attacking 'Rabbinic Judaism', then much of his argument is irrelevant, his abuse unmerited, and his conception of that which he was attacking inaccurate".

Other New Testament scholars quickly reacted on the thesis of Sanders. In his well-known T. W. Manson Memorial Lecture (1982), ${ }^{5}$ James Dunn coined the phrase "The New Perspective on Paul". The so-called New Perspective on Paul represents a considerable shift in the traditional Reformed or Lutheran interpretation of Paul that has dominated theological thinking for the last four centuries. The latter interpretation is in this context referred to as the so-called Old (Lutheran) Perspective on Paul. In his New Perspective on Paul, Dunn integrated and further developed the thesis of Sanders into his new understanding of Paul and his relationship to Israel and the law. Dunn focused on Paul's letter to the Galatians and discussed the key term el g wn nomou (works of the law), which occurs in Gal 2:16. His main argument, until this day, is that the efg wn nomou in this context refers to the circumcision which the false teachers compelled the believers to observe ( $\mathrm{Gal}$ 2:3-4) and the food laws with the resulting table fellowship rules that would be maintained ( Gal 2:14). The works of the law against which Paul is speaking here, refer in other words not to the law or good works as such, but to those works that served as boundary markers to mark off and separate Israel from the nations. ${ }^{6}$ Dunn saw parallels in other texts in which this perspective is explicitly present, for instance, Aristeas 139-142: "In his wisdom the legislator [i.e. Moses]... surrounded us with unbroken palisades and iron walls to prevent our mixing with any of the other peoples in any matter, being thus kept pure in body and soul...to prevent our being perverted by contact...." Dunn's study of Romans strengthened his perspective and led him further in the same direction. In Romans 3:27-30 the boasting on the grounds of the law are to be seen as works of the law that function in a way that reinforces 
Israel's exclusive claim on God in opposition to those who do not do the works of the law. Also in Romans 9:30-10:4, the focus on the works of the law and the relation to righteousness is to be understood as works of the law that clearly has the Jews in question believing that the latter set them apart from other nations. The law thus puts them in a superior position, over and against those who do not do the works of the law, or the specific boundary markers. For Paul, this view of the law and righteousness stood in antithesis to his own understanding of the universal dimension of faith and the inclusive character of the gospel he was called to preach. It was exactly this view that was radically transformed in his Damascus conversion (see Acts 9) when he was called by God to bring the gospel to the Gentiles - those who were excluded from the grace of God. Paul actively worked against the presupposition of the zealous Jews of his time who held the view that it is their duty to maintain Israel's set-apartness to God (cf. Levi, Phineas, Elijah, the Maccabees) and who saw themselves as "Jews by nature" and not "Gentile sinners" (Gal 2:15) - which represented the typical Jewish view of Gentiles. In 1994, Dunn's view which he developed more than a decade before was strengthened by the publication of the sectarian Qumran text, 4 QMMT in which the term "works of the law" explicitly appears and is linked to separation of the Qumran group from outsiders. Paul's problem with the Jewish believers in Galatians was that they treated the Gentiles with the "old condemning perspective" of Judaism that excluded the latter from fellowship with God and his people expressed amongst other things in their approach to table fellowship and circumcision (Dunn 2008:12-13). When Paul in Galatians speaks against the works of the law that do not have the ability to make one righteous, he is thus referring not to good works in general, but to those "boundary marker works" that separate Jews from Gentiles. Paul in other words appealed against those Jews in Antioch who insisted that Gentiles should "Judaize" (cf. Gal 2:14), in addition to faith, in order to become part of the community of faith ( $\mathrm{cf}$. Gal 2:16) and that these boundary markers are indispensable to salvation. Over and against this perspective Paul sees the gospel as having a universal scope (Rom 1:17), meant for all those who believe, signifying Gentile as well as Jew. Accordingly, Paul's teaching on justification focuses on the necessity to overcome the zealous barrier which the law was seen to interpose between Gentile and Jew (Dunn 2008:16-17).

\section{The Implication for Mission and Ethics}

Dunn's New Perspective on Paul has implications for the understanding of the dynamic relationship between mission and ethics in Paul. The term "works of the law" had an ethical dimension to it in the sense that it related to questions on identity, ethics and ethos (see Van der Watt 2006:v-ix). The Jews held extremely inclusive beliefs with regard to whom they were to socialise and interact with, that were amongst other things reflected in their dietary regulations and food laws. These food laws served as important ritual markers of Jewish identity: 
The limits of acceptable table fellowship between a Jew and a Gentile would be determined by two factors: (1) the Deuteronomic laws in Leviticus 11 and Deuteronomy 14:3-21, and (2) the various halakoth (halāk̂tô, 'ways') of the oral tradition. For the most part these laws and traditions primarily concerned the production and consumption of food and the appropriate environment in which consumption took place. J. Neusner has stressed that during the NT era one primary mark of Pharisaic commitment was the observance of the laws of ritual purity outside of the Temple, where everyone kept them. Eating one's secular, that is, unconsecrated food in a state of ritual purity, as if one were a Temple priest in the cult, was one of the two significations of party membership. Moreover, the agricultural laws, just like the purity rules, in the end affected table-fellowship, namely what one may eat (Neusner 1984:57). After a detailed examination of rabbinical traditions concerning the Pharisees, involving 341 case rulings, Neusner concludes that 'no fewer than 229 directly or indirectly pertain to table-fellowship, approximately $67 \%$ of the whole' (Neusner 1973: 86). In this respect the Pharisees can be called an 'Eating Club' (Neusner 1982). (Hawthorne, Martin \& Reid 1993:306)

In the Galatian controversy (see Dunn 1983), the opposing Jewish Christian false teachers insisted that the Gentile converts be subjected to certain "works of the law" on a behavioural level (ethics and ethos), namely to keep certain typical Jewish-cultural table fellowship rules, religious days and feasts, and have themselves circumcised. These behavioural categories are imbedded within a particular understanding of Jewishparticularistic socio-religious and cultural identity, as Dunn (1983:2007) pointed out. The opponents imposed a certain identity on the community of faith in Galatia who already formed a sociological group with its own self- understanding and way of life (manner of sociological interaction based on a new symbolic universe). The imposing of new behavioural categories by the opponents based on a particular sense of Jewish identity could not be possible without the deconstruction of power structures. The opponents therefore deconstructed the authority of Paul as apostle by claiming that they represented those who were apostles before Paul. In this way the status of Paul as apostle and his authority was put into question (see Gal 1:6-10; 4:17, 21-31; 5:10; 6:1118). The implication and practical outworking of the new/different gospel of the false teachers would have resulted in the inclusion of some and the exclusion of others, due to the character of the "€́ $\rho \gamma \omega \nu \nu$ ó $\mu$ ov as (socio-religious and cultural) boundary markers. The new teaching re-established elements of the law which inherently created social distinctions between Jews and Gentiles (circumcision, Sabbath-keeping, food laws). This would have direct implications with regard to the dynamics of the missionary process and the scope and intention of the gospel as a liberating message to all who believed, and not only those who become like Jews. On a historical level, it seems that it was at the apostle meeting in Jerusalem in 48/49 A.D. that the issue of gentile converts and the works of the law was resolved to some degree at least. At this conference, the resolution of the issue whether Gentiles should Judaize, and the subsequent decision that Jewish identity markers would not be imposed on Gentiles, resulted in the acknowledgement of Paul's missionary calling to the Gentiles (Gal 2:9; Acts 15). In other words, the solution to the question about the particularistic Jewish practices stood in a direct relationship 
to the acknowledgement of the universal missionary commission of Paul. Argued from the opposite direction, the maintenance/imposing of the pre-Jerusalem council point of view would implicitly entail a rejection of Paul's universal missionary calling - or would at least have an effect on it.

The false teachers' proposed ethos (circumcision and table fellowship rules, etc.) and its relation to identity inevitably would have resulted in the creation of new boundaries between the community of faith and its relationship to the outside world. In Gal 6:10 Paul encourages the community of faith to especially show love towards each other, but nonetheless also do good to those outside of the community of faith (cf. $\epsilon \rho \gamma a \zeta \omega \dot{\omega} \mu \in a$

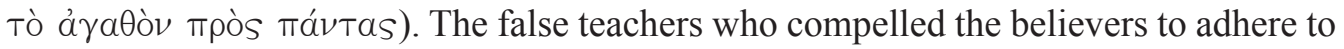
"works of the law" (food laws, etc) would have resulted in the Abgrenzung of the faith community (who adhered to the " of it which would have had direct implications for Paul's theology of mission. The dimension of outreach would have been limited to those with whom one could share table fellowship, and only those who shared the same Jewish particularistic works of the law or boundary markers would have become part of the community of faith. In other words, not faith, but specific Jewish cultural practices (ethos) would have determined who could get in, and who had to stay outside.

This went against the grain of Paul's missional theology and its inclusive universalistic approach. For Paul, the gospel, from the perspective of a high Christology (Jesus is Lord over all), transcended particularistic Jewish cultural-religious badges. In other words, according to Paul, Gentiles did not need to become Jews in order to become Christians.

Paul soon reacted to the false teachings amongst his community of faith and in his correspondence to the Galatian community he re-established his status as apostle (Gal 2:1ff.). He also emphasised the fact that the message he preached was not received by men, but by Jesus Christ himself through the process of divine revelation (Gal 1:11). In this way Paul deconstructed the message and authority of the false teachers, by using an

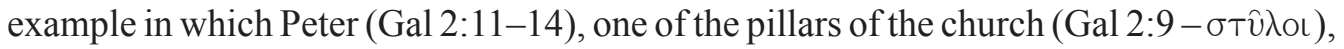
is presented as an inconsistent moral agent who regresses into old excluding behavioural categories that by implication strengthened the boundary lines between believing Jews and believing Gentiles. In this way Peter is presented as turning his back on those with

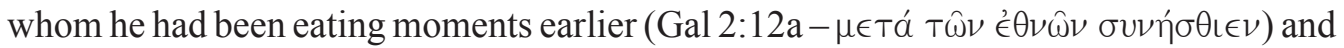

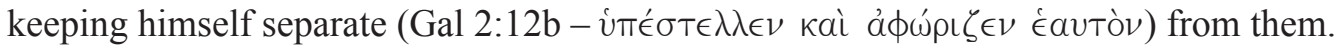
Over and against this picture, Paul is presented as the one who has been consistent from the beginning - the one that should be trusted as the original bringer of the true gospel of reconciliation that represents the message and intent of Jesus (and God) himself. The message of reconciliation becomes apparent exactly within the context where the boundary markers, like that of the exclusivist food laws, are deconstructed. Hawthorne, Martin \& Reid (1993:306) are correct when they argue that meals within the context of Christian house gatherings can be seen as nothing less than an overt manifestation of 
reconciliation between the Jews and Gentiles in Christ. Earlier Meeks (1983:97) argued that by deconstructing and abandoning the traditional Jewish regulations governing food laws and by social interaction with outsiders the "Pauline Christians gave up one of the most effective ways by which the Jewish community had maintained its separate identity in the pagan society" (Meeks 1983:97). According to Hawthorne, Martin and Reid (1993:306) "the house church was the venue for the cultural disestablishment which was necessary for the founding of the church in a Jewish-Gentile milieu. While the Gentiles were admonished to respect Jewish sensibilities, the meals served in these house churches confirmed the central message of the gospel in the Christian community, the message of reconciliation" (on reconciliation in Paul [Versöhnen], see also Becker 1989:432-437). Once the particularistic, exclusivist ethnic works of the law are disestablished, there has to be a new category for inclusion and exclusion - a new core for a new theology. In Galatians Paul makes a strong case for the fact that faith (in Christ Jesus the Lord), and not particularistic Jewish cultural works of the law, will serve as the means of entrance into the community of faith and those who are righteous before God (Gal 2:15-16).

\section{Wright-sising Dunn on the Core of Paul's Theology?}

This brings us to the question of the centre of Paul's theology. Traditional protestant interpretation views Paul's teaching on righteousness or justification by faith as the centre of his theology. In response it could be asked whether Paul in his missionary preaching to the Gentiles focused his missionary message on justification by faith. N. T. Wright (1997:45, 88, 113, 114, 151 [see also Wright 2009]) is of the opinion that this was not the case at all. He is of the opinion that the core of Paul's missionary preaching (contra Dunn) revolved around the proclamation of the death and resurrection of Jesus Christ, Son of God and Messiah - the One who fulfilled Israel's expectations.

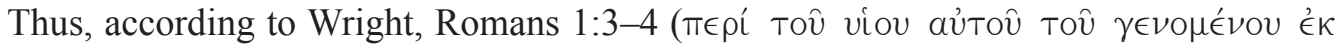

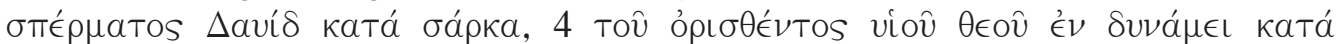

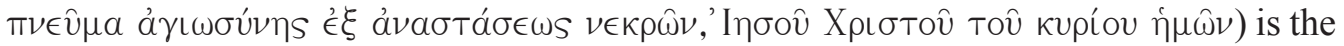

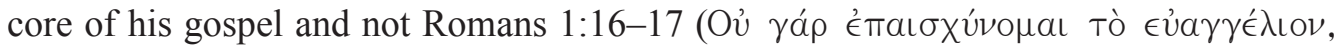

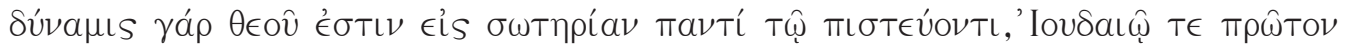

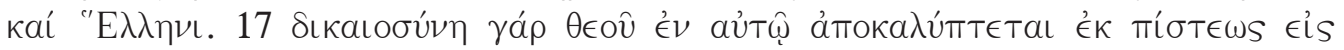

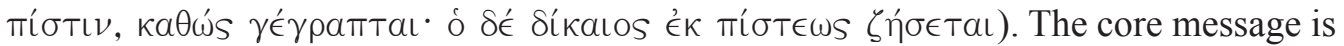
thus the proclamation of the fact that Jesus Christ is Lord, and not Caesar. The dimension of justification does not form the centre of Paul's preaching but is simply a result of faith in Christ's Lordship. Faith is the means by which a person becomes part of the

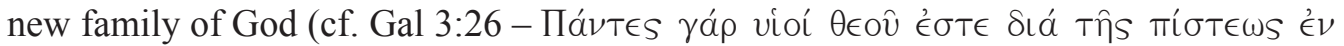
X

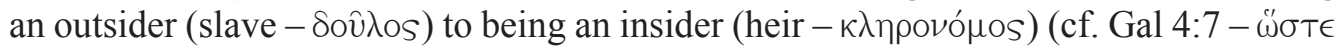

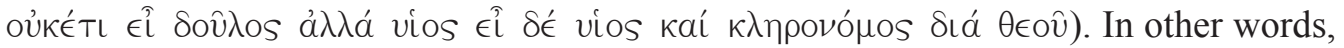


according to Wright, the preaching of the gospel and the coming to faith of believers is the centre of Paul's preaching. There where people are freed from the grip of sin and death (cf. Gal 3:22), there the core of the gospel is seen in action. It is also interesting to note that this concept is also expressed in Galatians 3:22 where Paul discusses the difference between those who are slaves and those who are sons (children) of God (Gal 3:21-4:7): The problem with the world is that all people are caught up in the grip of

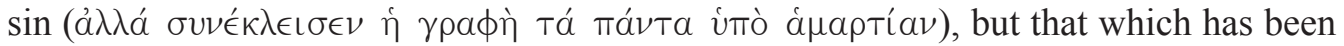

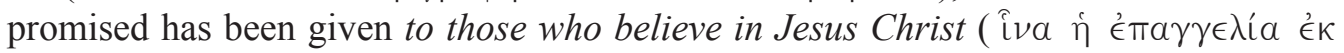

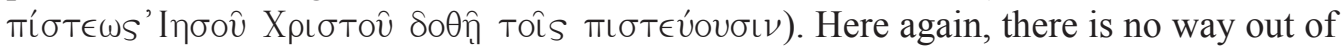
the grip of sin, and no access to the promises except through faith. We could thus agree with Wright that faith in the gospel (namely that Jesus is Lord) is the core message and pivotal point in Paul: For Wright, God's covenant faithfulness (righteousness) was fulfilled in the death and resurrection of Jesus who was nothing less than the expected Messiah (cf. Rom 1:4). Thus, the heart of Paul's theology is his fundamental covenant theology (cf. Rom 6) (Wright 2003:3). By saying that Jesus is Lord and Messiah, is in other words a way of saying, among other things, "Israel's history has come to its climax" and the prophecies of Isaiah (cf. Isa 40, 52) have been fulfilled (Rom 1:4).

In the time of Paul, the word "gospel" designated the message that Caesar was Lord. The gospel message of Paul boldly claimed that Jesus Christ, and not Caesar is Lord, and that he should be worshipped (cf. Phil 2:5-11). This was in direct opposition to the emperor cult and the power structures of the day. For Wright, the latter lies at the heart of his so called "fresh perspectives on Paul" - namely the "discovery of a subversive political dimension not as an add-on to Paul's theology but as part of the inner meaning of 'gospel', 'righteousness', and so on" (Wright 2003:3).

This of course touched on Paul's missionary dimension. When Paul as missionary proclaimed the gospel, he naturally started by proclaiming who Jesus was, and explained the significance of the death and resurrection of Jesus. For Paul, the proclamation of the gospel was closely related to the working of the Spirit. The moment some of those who hear and believe the message come to faith, then Paul admits that it was a direct result not of his oratory brilliance but a result of the Spirit, for " $[\mathrm{n}] \mathrm{o}$ person can say 'Jesus is Lord' except by the Holy Spirit". Where the gospel is thus preached and believed, there the Spirit is at work. Thus, the proclamation of the gospel (the significance of the death and resurrection of Jesus, Messiah and Lord) functions as the means of grace and the vehicle of the Spirit (Wright 2003:5). Furthermore, the proclamation of the gospel is a royal summons to submission, to obedience, to allegiance; and the form that this submission and obedient allegiance takes is nothing less than faith. Paul's expression "the obedience of faith" is in other words essentially performative - it compels the believer not only towards a particular reorientation in the context of a new family/social group but also towards a new way of life. Faith changes the believer's existential reality and is closely related to a new lifestyle (ethics). 


\section{Righteousness in Paul - Subjective or Objective Genitive?}

Here it is necessary to discuss the concept of righteousness (dikaiosune theou) and the role it played in Paul's theology. Scholars agree that almost in all instances where Paul discusses justification, he does so in the context of a critique of Judaism and with regard to the issue of the relationship between Jew and Gentile and the coming together of these two groups in Christ. Wright (2003:6) is still, after many years, of the opinion that when Paul uses this phrase it denotes not the status which God's people have from him or in his presence, but the righteousness of God himself. The righteousness of God is linked to the covenant God made with Israel and the righteousness of God refers to God's faithfulness and therefore could be seen as a form of justice (covenant-justice according to Wright). Because of God's faithfulness, he saves Israel and sends Jesus Messiah as Lord who fulfils the expectations of the covenant. Thus, the proclamation of the gospel is another way of saying God is righteous after all - he stayed true to the covenant and saved Israel. The other side of God's righteousness is the necessary judgement on those who did not stay true to the covenant - and therefore the righteousness of God inevitably also entails the judgement of people at the end of time (Rom 2:16- $\dot{\epsilon} v$

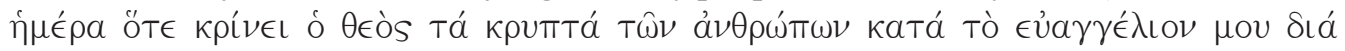

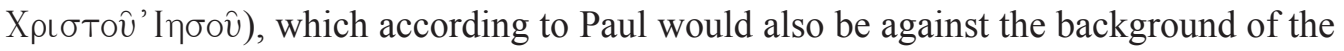

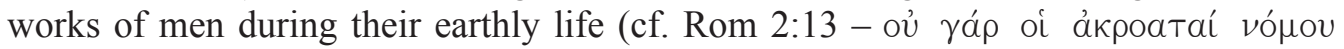

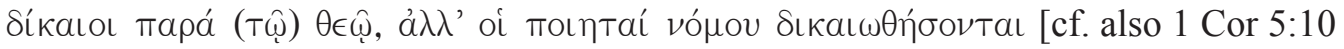

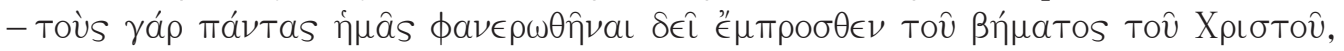

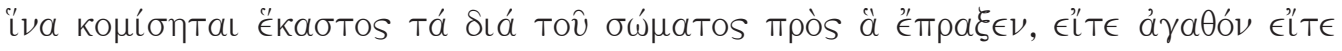

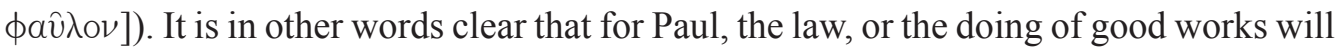
be taken into consideration at the final judgement. Thus Paul is not against the doing of good works per se (see Bachmann 2008:29). In fact, it is Selbsverständlicher-weise seen as linked to faith and seen as a consequent outworking of faith (Gal 5:22ff.). Faith in Christ thus has direct ethical implications. The question at the end of time would thus be - who would be found as those who belong to God's covenant people? This question is dealt with in Rom 9-11. Wright (2003:6) makes a strong argument that the covenant with Israel was from the beginning (cf. Gen 12:3; Isa 40-55) always designed to be God's means of saving and blessing the entire cosmos (see especially Gen 12:3). Therefore, the fulfilment of the covenant inherently had to have an inclusive universal dimension - not only Israel was in scope but all nations, Gentiles and Barbarians alike.

In one of the pre-graduate classes on this subject, one of my students, after hearing about Wright's perspective outlined above, asked whether this means that the Old Perspective on Paul is like the television show "Survivor". He then went on to explain that it seems to him that some in the old perspective thinking saw Christian faith as a form of immunity - namely that when the tribal council takes place, they will not be voted out because they have this special necklace that says they are believers. Now he 
understands that it is not true that a believer by implication has immunity just because he/she believes, but that works are still very important. If you do not have works, you will be judged. The only question he now faced was whether righteousness functions like someone's facebook status in the sense that one day your status is active and minutes later your facebook status is terminated. This creative analogical question got down right to the point.

Wright (2003:7) deals exactly with this question when he later discusses the question of how to understand the righteous status that believers enjoy. He argues that

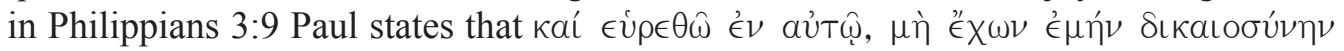

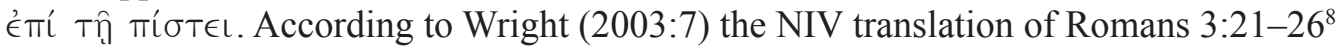
has it totally wrong. In the latter translation it becomes apparent that the dikaiosune theou is interpreted as "a righteousness from God" instead of God's righteousness (difference between an objective and a subjective genitive). This of course has important implications for the way we should understand the status of "righteous" that is enjoyed by God's people in Christ.

To solve this exegetical problem, Wright (2003:7-8) metaphorically turns to the forensic context of the Jewish law court:

In the Jewish law court Paul would have known, there is no Director of Public Prosecutions; there is a judge, with a plaintiff and a defendant appearing before him. When the case has been heard, the judge finds in favour of one party and against the other. Once that has happened, the vindicated party possesses the status 'righteous' - not itself a moral statement, we note, but a statement of how things stand in terms of the now completed lawsuit. When either the plaintiff or the defendant is declared 'righteous' at the end of the case, there is no sense that in either case the judge's own righteousness has been passed on to them, by imputation, impartation, or any other process. What they have is a status of 'righteous' which comes from the judge. Let me stress, in particular, that when the judge finds in favour of one party or the other, he quite literally makes them righteous; because 'righteous' at this point is not a word denoting moral character, but only and precisely the status that you have when the court has found in your favour.

When the believer thus has been declared "righteous" by God or has received the status of a righteous person, it does not refer to imputation as if the believer obtains the righteousness of God or the righteousness of Christ. As believers, we become children in the new family of the righteous God. We do not possess God's righteousness in us but have simply been declared righteous by the righteous God - due to the fact that we have come into the right relationship with him.

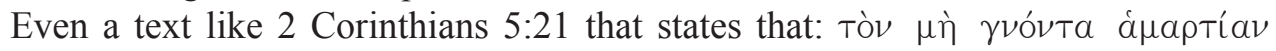

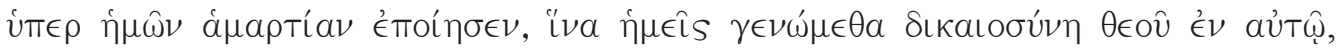
should not be seen to mean that believers have the righteousness of God. According to Wright (2003:8) it simply means that in Christ those who are called to be apostolic preachers actually embody God's own covenant faithfulness. The righteousness they embody in other words points to God's righteousness. The righteousness of believers is thus representational in character in the sense that it represents the righteousness of 
God; the righteousness of believers is thus like a mirror in the sense that in it people will see God and his righteousness.

\section{$5 \quad$ Will Christians Be Judged by Works After All?}

If Wright's train of thought is followed, it will naturally lead to the question of works or applied and implied Christian ethics. If, as Meeks (1993:94) rightly points out, there is no distinction to be made between Jew and Gentile on the grounds of the equal standing before God, one inevitably has to ask whether or not the manifestation of God's righteousness is suddenly to be seen apart from the law. In other words, in the missionary process and reimagining and retelling of what the righteousness of God means against the background of the Christ event, the ethical dimension and relationship to the law was of crucial importance. Important questions naturally arise in this context: What will be the shape of the (new) moral life? Will Christians, who in the missionary process have become part of the new family of God, be judged according to works during the final eschatological judgment? Will they suddenly discover that their righteous status has been terminated, that they never had immunity, and that they have just been voted off from the island? Wright is straight to the point and replies with an unambiguous "yes":

Paul, in company with mainstream second-Temple Judaism, affirms that God's final judgment will be in accordance with the entirety of a life led - in accordance, in other words, with works. He says this clearly and unambiguously in Romans $14.10-12$ and 2 Corinthians 5.10 . He affirms it in that terrifying passage about church-builders in 1 Corinthians 3. But the main passage in question is of course Romans 2.1-16 (Wright 2003:8).

Believers will in other words also stand in front of God's (righteous) judgement seat. This aspect of Paul's theology has been overlooked due to the traditional Reformed view on justification, contrary to the apostle Paul's own words about the matter. There are many passages that deal with Paul's view of the final judgment (cf. 2 Cor 5:10 -

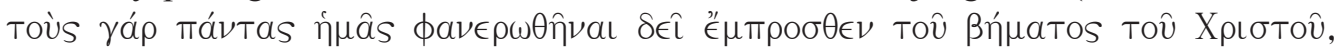

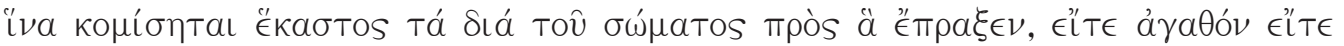

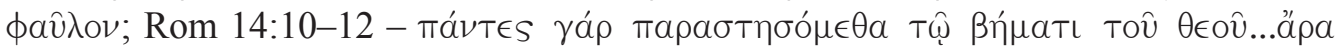

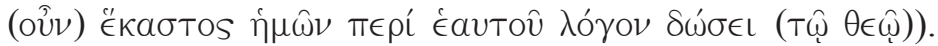

Wright explains this point further by referring to Romans 2:1-16 where Paul argues

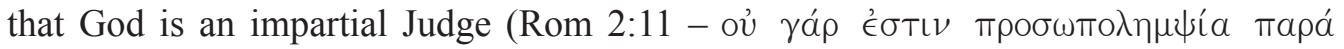

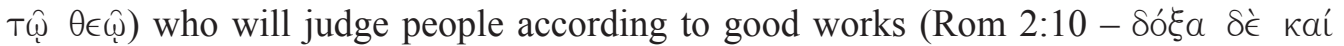

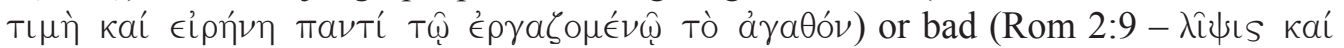

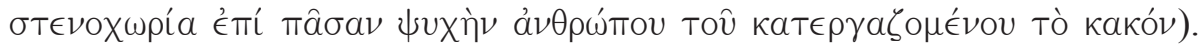

It is however important to note that we do not here have to do with the moralistic view of works-righteousness! These works are the fruit (cf. Gal 5:22) of those who let their lives be guided by the Spirit (Gal 5:16,18) who equips the believers (Gal 3:5). These works in reality illustrate that the believer is really in Christ and the resulting 
works are produced by the indwelling of the Spirit. It is thus almost an automatic result of a life in Christ (Gal 3:26). The Spirit is able to do what the law could not, namely to give life (Rom 8:1-17 in relation to 2:1-16; Gal 5:22) - and that within the context of life shaped by a high moral consciousness. Wright (2003:9) points to the fact that Paul is clear "that the things he does in the present, by moral and physical effort, will count to his credit on the last day, precisely because they are the effective signs that the Spirit of the living Christ has been at work in him" (see also 1 Thess 3:19f.; cf. Phil 2:16; 1 Cor 15:10; Col 1:29). Therefore, only at the end judgment will we be declared righteous, (if our works proved that we were in Christ [Rom 2:7]) and only then will we be justified (Rom 2:13). This brings Wright (2003:9) to the important statement that justification is the "anticipation in the present of the justification which will occur in the future, and gains its meaning from that anticipation".

\section{On Our Way to Salvation - Living Our Calling}

Wright (2003:10) argues convincingly that in traditional old perspective protestant thinking the terms conversion and justification have often been interpreted as coterminous. This particular perspective distorts the view Paul had on the matter and certainly maintains traditional old perspective interpretation. The interesting fact Wright points to is that Paul did not see it this way. The word(s) Paul uses when he refers to that moment when the gospel is heard and people come to faith, is not "conversion" or "justification" but "calling" (cf. 1 Cor 1:26; 7:20; Phil 3:14; especially Rom 11:29). Wright (2003:10) postulates: "For Paul, the word 'call' denoted not merely a vocation to a particular task but also, more fundamentally, the effective call of the gospel, applied by the Spirit to the individual heart and life and resulting in a turning away from idolatry and sin and a lifelong turning to God in Christ in believing allegiance." It is exactly at this point where Wright's fresh perspective differs from the old protestant perspective. Justification follows the calling - it happens subsequent to the calling, and functions as a declaration. The word "justify" should in other words not be used to denote "conversion" as the protestant interpretation sees it; for Wright (2003:11) "justification is something that follows on from the 'call' through which a sinner is summoned to turn from idols and serve the living God, to turn from sin and follow Christ, to turn from death and believe in the God who raised Jesus from the dead". The moment of calling is the start of a process in which $\mathrm{He}(\mathrm{God})$ that started it all will bring it to completion (Phil 1:6-

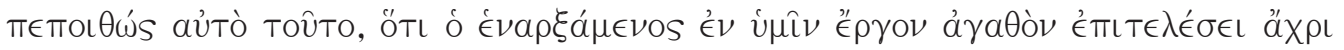

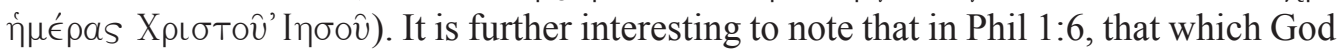

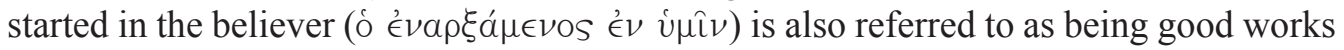

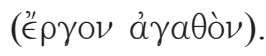




\section{If Justification Is Not Conversion - What Is It?}

How is justification to be understood if it is not to be equated with conversion? This could be explained best by Wright's forensic metaphor of the judge that declares someone righteous, discussed above. Justification is thus to be understood as a declarative word - when the judge declares that something is (already) the case. When God declares someone as "justified" he declares that someone is in the right, and that this person is now part of the (universal: Jew/Gentile) covenant family and no longer outside of it. This all happens against the background of God's covenant (and Paul's underlying covenantal theology). Here God's declaration of forgiveness of sins and declaration of covenant membership is one and the same thing: those who were sinners (Jews and Gentiles) are now part of the newly created covenant family of God (Rom 3:21-31) where all people are equal before God. Consequently, Wright may be right when he proposes that this is how the controversy in Gal 2:11-22 should be understood. Perhaps it had less to do with "how" one becomes a Christian but more to do with "who" should be part of this new covenant family and "why" Jewish-particularistic ethnic works of the law are not those that will constitute the required works that will bring a person into the covenant relationship. Wright (2003:13-14) argues his point convincingly:

And we now discover that this declaration, this vindication, occurs twice. It occurs in the future, as we have seen, on the basis of the entire life a person has led in the power of the Spirit - that is, it occurs on the basis of 'works' in Paul's redefined sense. And, near the heart of Paul's theology, it occurs in the present as an anticipation of that future verdict, when someone, responding in believing obedience to the 'call' of the gospel, believes that Jesus is Lord and that God raised him from the dead. This is the point about justification by faith - to revert to the familiar terminology: it is the anticipation in the present of the verdict which will be reaffirmed in the future. Justification is not 'how someone becomes a Christian'. It is God's declaration about the person who has just become a Christian. And, just as the final declaration will consist, not of words so much as of an event, namely, the resurrection of the person concerned into a glorious body like that of the risen Jesus, so the present declaration consists, not so much of words, though words there may be, but of an event, the event in which one dies with the Messiah and rises to new life with him, anticipating that final resurrection.

The important thing to realise is that justification in Paul is not to be seen as how someone could get into God's covenant people, but God's declaration that someone actually is in, already. Those who are in, should live accordingly - like those who are in. If they do not, it says nothing of God's righteousness but something of their own personal commitment to God. So, Wright $(2003: 14)$ is correct that we should make sure that we understand that we are not justified by faith by simply believing in justification by faith. We are justified by believing in the gospel and living accordingly.

According to me, justification is nothing less than the missionary message of reconciliation. It is the message that people who were estranged from God are now declared to be in the right with God. It is furthermore also the message of reconciliation that declares the fact that there will be no more ethnic and cultural walls of division and 
therefore it becomes imperative to do good to all (cf. Gal 6:10). In missional theology we should therefore not make the mistake to impose Western cultural paradigms or ethos as the means of converting people (see Campbell 2005:90), but realise that Paul, in a time of radical ethnic and tribal sensitivities, was a revolutionary figure in his time who deconstructed such divisive ethnic particularities in favour of an inclusive universal missionary movement.

\section{NOTES}

1 I agree with Wright (2003:1-2) that it is no longer possible to speak in the singular form of the New Perspective of Paul, for there are today many different streams of new or "fresh" (N. T. Wright) perspectives on Paul.

2 One example is that of Pope John Paul II who at the German Rabbinical Conference in Mainz during the end of the year 1980 referred to the Jews being "the people of God of the old covenant never revoked by God".

3 Weber (1880). For the complete text of Weber's book, visit the following internet address: http:// www.archive.org/stream/systemderaltsyn00unkngoog\#page/n6/mode/1up

4 Against those who argue that the Gospels appear to have a negative view of Judaism and especially Pharisaism, which is closer to the Weber-Bousset-Bultmann point of view, Sanders argued that the latter is the result of the polemical nature of the tension between the early church and Judaism, and does not represent the view of Judaism itself. In other words, in a polemical situation one will often find the use of vilification as a strategy. On vilification used against the Pharisees in the Gospel of John, see Van der Watt \& Kok (2008a:1793-1812) as well as Van der Watt \& Kok (2008b:1813-1835).

5 See Wright (1990).

6 Dunn (2008:9) developed this perspective after extensive discussions with H Räisänen on the question revolving around the problematic Galatians 3:10 in which Paul argues that those who trust in the law fall under a curse.

7 Quoted by Dunn (2008:9).

8 The NIV translates Romans 3:21-26 as follows: 21 But now a righteousness from God, apart from law, has been made known, to which the Law and the Prophets testify. 22 This righteousness from God comes through faith in Jesus Christ to all who believe. There is no difference, 23 for all have sinned and fall short of the glory of God, 24 and are justified freely by his grace through the redemption that came by Christ Jesus. 25 God presented him as a sacrifice of atonement, through faith in his blood. He did this to demonstrate his justice, because in his forbearance he had left the sins committed beforehand unpunished -26 he did it to demonstrate his justice at the present time, so as to be just and the one who justifies those who have faith in Jesus. 


\section{BIBLIOGRAPHY}

Bachmann, M. 2008. Anti-Judaism in Galatians. Exegetical studies on a polemical letter and on Paul's theology. Eerdmans, Grand Rapids.

Becker, J. 1989. Paulus. Der Apostel der Völker. Mohr Siebeck, Tübingen.

Campbell, J. S. 2005. The way of Jesus. Jossey-Bass, San Francisco.

Dunn, J. D. G. 1983. The incident at Antioch (Gal 2:11-18). JSNT 18:3-57

Dunn, J. D. G. 2008. The new perspective on Paul. Eerdmans, Grand Rapids.

Gagner, J. G. 2000. Reinventing Paul. Oxford University Press, New York.

Hawthorne, G. F., R. P. Martin \& D. G. Reid 1993. Dictionary of Paul and his letters (306). InterVarsity Press, Downers Grove, Ill.

Meeks, W. A. 1983. The first urban Christians: The social world of the apostle Paul. Yale University, New Haven.

Meeks, W.A. 1993. The moral world of the first Christians. Yale University Press, London.

Montefiore, C. G. 1915. Judaism and St. Paul. Goschen, London.

Moore, G. F. 1930. Judaism in the first centuries of the Christian era: The age of the Tannaim. Harvard, Cambridge, Mass.

Neusner, J. 1973. From politics to piety: The emergence of Pharisaic Judaism. Prentice Hall, Englewood Cliffs, NJ.

Neusner, J. 1982. Two pictures of the Pharisees: Philosophical Circle or Eating Club. ATR 64:525-57

Neusner, J. 1984. Judaism in the beginning of Christianity. Fortress, Philadelphia.

Parkes, J. 1936. Jesus, Paul and the Jews. SCM, London.

Sanders, E. P. 1977. Paul and Palestinian Judaism. SCM, London.

Stendahl, K. 1963. The apostle Paul and the introspective conscience of the West. HTR 65:199-215.

Stendahl, K. 1976. Paul among Jews and Gentiles. SCM, London.

Van der Watt, J. G. (editor) 2006. Identity, ethics and ethos in the New Testament. BZNW 141. De Gruyter, Berlin.

Van der Watt, J. G. \& J. Kok 2008a. Geweld in 'n evangelie van liefde: Die Evangelie van Johannes se perspektief op geweld teen Jesus en sy dissipels. HTS 64(4):1793-1812.

Van der Watt, J. G. \& J. Kok 2008b. Jesus en sy dissipels se reaksie op geweld in die Johannesevangelie. HTS 64(4):1813-1835.

Weber, F. W. 1880. System der altsynagogalen palästinischen Theologie: Aus Targum, Midrasch und Talmud. Dörffling \& Franke, Leipzig.

Wright, N. T. 1990. Jesus, Paul, and the Law: Studies in Mark and Galatians. Westminster/John Knox Press, Louisville, KY.

Wright, N. T. 1997. What St. Paul really said: Was Paul of Tarsus the real founder of Christianity? Eerdmans, Grand Rapids.

Wright, N. T. 2003. New Perspectives on Paul. Unpublished Conference Paper. 10th Edinburgh Dogmatics Conference 25-28 August, Rutherford House, Edinburgh.

Wright, N. T. 2009. Justification: God's plan and Paul's vision. SPCK, London. 